\title{
₹USGS
}

science for a changing world

\section{Preliminary analyses for perchlorate in selected natural materials and their derivative products}

by G.J . Orris ${ }^{1}$, G.J . Harvey ${ }^{2}$, D.T. Tsui ${ }^{3}$, and J .E. Eldrige ${ }^{4}$

Open-File Report 03-314

2003

This report has not been review ed for conformity with U.S. Geological Survey editorial standards. Any use of trade, firm, or product names is for descriptive purposes only and does not imply endorsement by the U.S. Government.

U.S. DEPARTM ENT OF THE INTERIOR

U.S. GEOLOGICAL SURVEY

USGS, Tucson, Arizona

${ }^{2}$ W right-Patterson AFB, Ohio

${ }^{3}$ Los Angeles AFB, California

${ }^{4}$ Air Force Academy, Colorado Springs, Colorado 


\section{INTRODUCTION}

Increasing concern about sources of perchlorate contamination in ground and surface waters has led to interest in identifying potential sources of natural perchlorate and products derived from these natural sources. To date, most perchlorate found in ground and surface waters has been attributed to its major uses as an oxidizer in solid propellants for rockets, in fireworks and other explosives, and a variety of other uses of man-made perchlorate salts. However, perchlorate found in the soils, surface water, and ground water of some locations cannot be linked to an anthropogenic source. This paper contains preliminary data on the detection and non-detection of perchlorate in a variety of natural materials and their products, including some fertilizer materials. These data were previously presented at two conferences; once in poster session and once orally (Harvey and others, 1999; Orris and others, 2000). Although the results presented here are included in a journal article awaiting publication, the lack of public information on this topic has led to repeated requests for the data used as the basis for our presentations in 1999 and 2000.

\section{BACKGROUND}

Perchlorate acid and its ammonium, potassium, and sodium salts have numerous industrial and military uses. Because the perchlorate anion $\left(\mathrm{ClO}_{4}^{-}\right)$can block iodine uptake in the thyroid and impact thyroid function, it has the potential to affect metabolism, growth, and development in animals. Recent advances in our ability to detect perchlorate at lower concentrations have resulted in the identification of this anion in the surface and (or) ground water of sites in more than 20 states in the U.S. It is anticipated that, as more areas are tested, additional areas with perchlorate-bearing water will be identified both within, and outside, the U.S. The presence of perchlorate in ground and surface water has most frequently been attributed to the manufacture and use of perchlorates for propellants in rocket and missile fuel. However, recent studies indicate that some perchlorate in soils, surface water, and groundwater may originate from natural sources and, locally, from the past use of some types of fertilizers (i.e., Chilean nitrates).

Perchlorates in fertilizers were first identified in the 1880's in natural nitrate fertilizers from deposits in the Atacama Desert of northern Chile (Schumacher, 1960); later studies by George Ericksen of the U.S. Geological Survey and other workers also identified perchlorate in this material (Ericksen, 1981; Van Moort, 1985). By 1999, the EPA was testing for the presence of perchlorate in some fertilizers and fertilizer components that did not contain natural Chilean nitrate. The report of perchlorate in some of theses analyzed natural fertilizer materials, such as limestone (Susarla and others, 1999), was surprising for geological and geochemical reasons. In an effort to verify early reports from the EPA on the presence of perchlorate in fertilizer materials other than Chilean nitrates, we decided to test other minerals and materials that formed in environments geochemically and (or) geologically similar to that of the natural nitrates. The initial findings in most of the natural fertilizer materials (other than Chilean nitrates) tested by the EPA were not confirmed by later EPA testing (Susarla and others, 1999, 2000; Urbansky, 2000). However, we proceeded with our analyses of evaporites and other materials because of the factors similar to those of Chilean 
nitrates. In 2002, the EPA reported finding perchlorate in three solid nitrate fertilizers used for hydroponics (Collette and others, 2002).

The difficulty in identifying the form of the perchlorate in natural materials has in the past led to questions about the methodology for the detection of perchlorate and the geologic feasibility of naturally occurring perchlorate. However, the presence of perchlorate in some minerals and other evaporite materials other than Chilean nitrates indicate $s$ that natural geochemical processes can produce perchlorate. Some of the factors related to the natural formation of nitrates would also seem to be necessary for the formation of natural perchlorates. These factors include aridity and the presence of salines and related minerals (Ericksen, 1983). In 1983, Ericksen suggested that most nitrates in the Chilean deposits have a biogenic origin and that most of the nitrate formed by fixation of atmospheric nitrogen by microorganisms in playas and associated moist soils. He believed that leaching and redeposition of the saline materials by infrequent rainwater led to concentration of the nitrates. Ericksen suggested that the perchlorate may have formed by photochemical reactions between chlorine and ozone and that the perchlorate was concentrated by the same mechanism that concentrated the nitrates. It might also be possible that the perchlorate has a biogenic origin such as that envisioned for nitrates by Ericksen. Formation and concentration of perchlorate under these conditions could lead to a high degree of variability in the perchlorate content of permissive geologic units; this variability could be compounded or mitigated by the processing and handling required to produce fertilizer components and other derivative products, as well as the variable experience and capabilities of the labs conducting the analyses.

\section{SAMPLES AND SAMPLE ANALYSIS}

Samples of evaporite-related minerals and surface crusts were pulled from sample sets collected by the USGS for other studies and submitted for analysis to the laboratory at Wright-Patterson Air Force Base. Samples included potash ore from potash deposits in Saskatchewan (Canada) and New Mexico. Additional samples of natural materials included playa crusts from Bolivia and California, as well as a hanksite $\left(\mathrm{Na}_{22} \mathrm{~K}\left(\mathrm{SO}_{4}\right)_{9}\left(\mathrm{CO}_{3}\right)_{2} \mathrm{Cl}\right)$ crystal from Searles Lake, California, and a sample of kelp. After initial positive results were discovered, some related and (or) derivative non-liquid consumer products such as "lite" salt, blood and fishmeal, and commercial fertilizers were tested for perchlorate.

One gram of each sample was suspended in $30 \mathrm{~mL}$ of de-ionized water in a 40-mL scintillation vial. The suspension was shaken on a HaakeBuchler Vortexer-Evaporator overnight. The top $20 \mathrm{~mL}$ of the suspension was removed and placed in a 50-mL centrifuge tube. The samples were centrifuged for $20 \mathrm{~min}$ at $2500 \mathrm{rpm}$. Ten milliliters of the sample was sequentially filtered through an On Guard-Ag , $-\mathrm{H}$ and Millex-HV 0.45 micron cartridges and filters. Filtered samples were placed in 2-ml sample vials for analysis by Ion Chromatography (IC). IC analyses were performed on the samples using a Dionex DX 500 ion chromatography system, with a GP-40 gradient pump and a LC-20 chromatography enclosure. A Dionex Anion Self Regenerating SuppressorUltra (ASRS-Ultra), operating at $300 \mathrm{~mA}$ in external water mode was used to suppress background conductivity. The regeneration flow rate was set at $5 \mathrm{~mL} / \mathrm{min}$. The system also included a Dionex AS-3500 autosampler. All data were collected using Peak Net software. Ion separation was performed on a Dionex IonPak AS-16 guard column 
(4.0 x 50mm). An AG-16 guard column $(4.0 \times 50 \mathrm{~mm})$ and a Dionex ATC-1 anion trap column were used in conjunction with the AS-16 column for analysis. The mobile phase consisted of $35 \mathrm{mM} \mathrm{NaOH}$ at a flow rate of $1.25 \mathrm{~mL} / \mathrm{min}$. The injection loop was $1000 \mathrm{uL}$. The analysis was performed at 30 degrees Celsius. This technique and its reliability are described more fully in Tsui and others, 2000.

\section{RESULTS}

The results of our initial tests for perchlorate in natural materials and related products are given in table 1 . Of the natural minerals and other materials tested, significant perchlorate $(>1000 \mathrm{ppm})$ was detected in three samples of potash ore (Potash Ore 1 and 2 from New Mexico, Potash Ore 3 from Saskatchewan), two samples of playa crust (Playa Crust 1 and 2 from Bolivia), one sample of the mineral hanksite (Hanksite 1 from California), and one kelp sample. In addition, a few parts per billion of perchlorate were detected in the single samples of "bloodmeal" and "fishmeal" fertilizers. No perchlorate was detected in the samples of purchased products derived from potash $(\mathrm{KCl})$ ores, such as fertilizers and salt substitutes. It is unclear how representative these analyses are; duplicate analyses of some of the samples containing perchlorate verified the presence of perchlorate. Additional analyses of similar material collected under controlled conditions are planned. A better understanding of natural perchlorate occurrence, chemistry, and behavior under a variety of physical, chemical, and biologic conditions will require methodical research and more extensive sampling.

The preliminary results given in table 1 have been verified by further analyses; duplicates of some samples were analyzed at the Wright-Patterson lab or by an outside commercial lab.

\section{CONCLUSIONS}

Our studies found measurable perchlorate in natural potash-bearing evaporite samples from a variety of geologic environments, in kelp, and in some derivative products. Like the revised EPA results (Susarla and others, 2000), we did not find perchlorate in the limited number of limestone and phosphate ore samples tested. Most of the samples found to contain perchlorate have some conditions of formation or chemistry analogous with aspects in the theoretical conditions of Chilean nitrate formation. The hanksite, potash ore (sylvinite), and playa crust samples all formed in arid environments in conjunction with other saline minerals. All of the mineral and evaporite samples that contained perchlorate contained one or more potassium salts. The chlorine in the Chilean nitrates, the tested potash ores, and the kelp is of marine origin; the origin of the chlorine in the playa crust and hanksite samples is of uncertain origin, but may have been derived from older marine shales and (or) evaporates. The results of our preliminary analyses for perchlorate in natural materials does not negate our initial hypothesis that natural sources of perchlorate (other than Chilean nitrates) are most likely to occur in similar depositional environments, especially in arid climates with strong evaporitic conditions. As a next step, perchlorate analyses of earlier stage evaporates such as halite and gypsum need to be made to determine if perchlorate is restricted to, or more likely to occur in, the bittern portion of evaporite sequences. In addition, playa surfaces and potash occurrences need to be sampled and tested in a methodical way to help determine the distribution of perchlorate within these types of 
occurrences. Lastly, an effort needs to be made to determine the mode of occurrence of the perchlorate within the perchlorate-bearing samples.

Table 1. Perchlorate in natural minerals and materials and related products. [ppb, parts per billion; $\mathrm{kg}$, kilograms; L, liter; g/Kg, grams per kilogram; DUP, duplicate sample; NA, not applicable; ND, not detected; SP, spike; ppt, precipitate]

\begin{tabular}{|c|c|c|c|c|c|c|c|c|}
\hline Samples & $\begin{array}{r}\text { Meas } \\
\text { Concen } \\
(\mathrm{ppb})\end{array}$ & $\begin{array}{l}\text { ed } \\
\text { ation } \\
\text { Dilution } \\
\text { Factor }\end{array}$ & $\begin{array}{c}\text { Final } \\
\text { Concentration } \\
\text { In Extract } \\
\text { (ppb) }\end{array}$ & $\begin{array}{l}\text { MDL } \\
\text { (ppb) }\end{array}$ & $\begin{array}{c}\text { Spike } \\
\text { Recoveries } \\
\text { (percent) }\end{array}$ & $\begin{array}{c}\text { Sample } \\
\text { Weight } \\
(\mathrm{kg})\end{array}$ & $\begin{array}{l}\text { Extraction } \\
\text { Volume } \\
\text { (L) }\end{array}$ & $\begin{array}{c}\text { Concentration } \\
(\mathrm{g} / \mathrm{Kg})\end{array}$ \\
\hline Muriate Potash & ND & 1 & ND & 1 & & 0.001 & 0.03 & ND \\
\hline Mission Chem & ND & 1 & ND & 1 & & 0.001 & 0.03 & ND \\
\hline Miracle Grow & ND & 1 & ND & 1 & & 0.001 & 0.03 & ND \\
\hline Bonemeal, Brand 1 & ND & 1 & ND & 1 & & 0.001 & 0.03 & ND \\
\hline Bloodmeal, Brand 1 & 5.4 & 1 & 5.4 & 1 & & 0.001 & 0.03 & 0.161 \\
\hline Bloodmeal, Brand 1, DUP & 4.8 & 1 & 4.8 & 1 & $111 \%$ & 0.001 & 0.03 & NA \\
\hline Fishmeal & 9.2 & 1 & 9.2 & 1 & & 0.001 & 0.03 & 0.276 \\
\hline Fishmeal, DUP & 11.0 & 1 & 11 & 1 & $84 \%$ & 0.001 & 0.03 & NA \\
\hline Miracid & ND & 1 & ND & 1 & & 0.001 & 0.03 & ND \\
\hline Joebesi Fertilizer Spikes & ND & 1 & ND & 1 & & 0.001 & 0.03 & ND \\
\hline Peters Pro Plant Food & ND & 1 & ND & 1 & & 0.001 & 0.03 & ND \\
\hline Potash Fertilizer, Brand 1 & ND & 1 & ND & 1 & & 0.001 & 0.03 & ND \\
\hline Potash Fertilizer, Brand 1, DUP & ND & 1 & ND & 1 & & 0.001 & 0.03 & ND \\
\hline Great Salt Lake ppt & ND & 1 & ND & 1 & & 0.001 & 0.03 & ND \\
\hline Salt substitute, Brand 1 & ND & 1 & ND & 1 & & 0.001 & 0.03 & ND \\
\hline Salt substitute, Brand 1, DUP & ND & 1 & ND & 1 & & 0.001 & 0.03 & ND \\
\hline Salt substitute, Brand 2 & ND & 1 & ND & 1 & & 0.001 & 0.03 & ND \\
\hline Salt substitute, Brand 3 & ND & 1 & ND & 1 & & 0.001 & 0.03 & ND \\
\hline Lite Salt, Brand 1 & ND & 1 & ND & 1 & & 0.001 & 0.03 & ND \\
\hline Lite Salt, Brand 1, 50 ppbSP & 48.8 & 1 & 48.8 & 1 & $98 \%$ & 0.001 & 0.03 & NA \\
\hline Triple superphosphate & ND & 1 & ND & 1 & & 0.001 & 0.03 & ND \\
\hline Soft rock phosphate ore & ND & 1 & ND & 1 & & 0.001 & 0.03 & ND \\
\hline 10-10-10 fertilizer & ND & 1 & ND & 1 & & 0.001 & 0.03 & ND \\
\hline Urea & ND & 1 & ND & 1 & & 0.001 & 0.03 & ND \\
\hline 10-4-10 fertilizer & ND & 1 & ND & 1 & & 0.001 & 0.03 & ND \\
\hline Phosphate ore 1 & ND & 1 & ND & 1 & & 0.001 & 0.03 & ND \\
\hline Phosphate ore 2 & ND & 1 & ND & 1 & & 0.001 & 0.03 & ND \\
\hline Phosphate ore 3 & ND & 1 & ND & 1 & & 0.001 & 0.03 & ND \\
\hline Phosphate ore 4 & ND & 1 & ND & 1 & & 0.001 & 0.03 & ND \\
\hline Limestone & ND & 1 & ND & 1 & & 0.001 & 0.03 & ND \\
\hline Potash Ore 1 (sylvinite 1a) & 25000 & & - & & & 0.00114 & 0.03 & 0.025 \\
\hline Potash Ore 2 (sylvinite 1b) & 3741000 & & - & & & 0.00105 & 0.03 & 3.741 \\
\hline Potash Ore 3 (sylvinite 2) & 42000 & & - & & & 0.00104 & 0.03 & 0.042 \\
\hline Playa Crust 1 (B43) & 1745000 & & - & & & 0.00101 & 0.03 & 1.745 \\
\hline Playa Crust 2(B29) & 560000 & & - & & & 0.00101 & 0.03 & 0.560 \\
\hline Playa Crust 2 (B29), DUP & 489000 & & - & & & 0.00101 & 0.03 & 0.489 \\
\hline Hanksite 1 & 280000 & & - & & & 0.00116 & 0.03 & 0.280 \\
\hline Hanksite 1, DUP & 285000 & & - & & & 0.00116 & 0.03 & 0.285 \\
\hline Kelp & 885000 & & - & & & 0.00116 & 0.03 & 0.885 \\
\hline
\end{tabular}




\section{REFERENCES}

Collette, T.W., Williams, T.L., Urbansky, E.T., and others, 2002, Analysis of hydroponic fertilizer matrixes for perchlorate: comparison of analytical techniques: The Analyst, v. 128 , no. 1 , p. $88-97$.

Ericksen, G.E., 1981, Geology and origin of the Chilean nitrate deposits: United States Geological Survey Professional Paper 1188.

Ericksen, G.E., 1983, The Chilean nitrate deposits: American Scientist, v. 71, p. 366-374.

Harvey, G.J., Tsui, D.T., Eldrige, J.E., and Orris, G.J., 1999, Origins of perchlorate in natural and anthropogenic fertilizer products [abs.]: Society of Environmental Toxicology and Chemistry, 20th Annual Mtg., Philadelphia, Penn., Nov 14-18.

Orris, G.J., Harvey, G.J., Tsui, D.T., and Eldrige, J.E., 2000, Perchlorate in natural fertilizer materials-what do we really know? [abs.]: Forum on the Geology of Industrial Minerals, $36^{\text {th }}$, Bath, England, May 7-12.

Schumacher, J.C., ed., 1960, Perchlorates-their properties, manufacture and uses: New York, Reinhold Publishing Corp., 257 p.

Susarla, S., Collette, T.W., Garrison, A.W., Wolfe, N.L., and McCutcheon, S.C., 1999, Perchlorate identification in fertilizers: Environmental Science and Technology, v. 33, no. 19, p. 3469-3472.

Susarla, S., Collette, T.W., Garrison, A.W., Wolfe, N.L., and McCutcheon, S.C., 2000, Correction to perchlorate identification in fertilizers: Environmental Science and Technology, v. 34, no. 20, p. 4452-4453.

Tsui, D.T., Clewell, R.A., Eldridge, J.E., and Mattie, D.R., 2000, Perchlorate analysis with the AS16 separation column, in Urbansky,E.T., ed., Perchlorate in the environment: New York, Kluwer Academic/Plenum Publishers, p. 59-80.

Van Moort, J.C., 1985, Procesos naturales de enriquecimiento de iones nitrato, sulfato, perchlorato, iodato, borato, perchlordo, y cromato en los caliches del norte de Chile: Actas de IV Congreso Geológico Chileno, t. IV, p. 3.674-3.702.

Urbansky, E.T., Magnuson, M.L., and Kelty, C.A., 2000, Comment on "Perchlorate identification in fertilizers" and the subsequent addition/correction: Environmental Science and Technology, v. 34, p. 224. 